UDC: $637.4^{\top} 652 / 658$

COBISS.SR-ID: 228213004

Original research paper

Acta Agriculturae Serbica, Vol. XXI, 42 (2016); 145-154

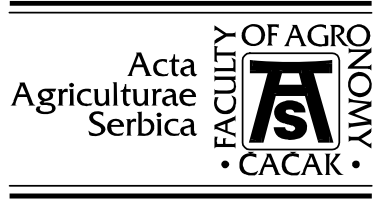

\title{
Impact on productivity of forced molt and duration of production cycle of commercial laying hens held in cage systems
}

\author{
Sreten Mitrović ${ }^{1}$, Tatjana Pandurević ${ }^{2 *}$, Maja Radoičić Dimitrijević ${ }^{1}$, \\ Milena Milojević ${ }^{1}$ Julijana Trifković ${ }^{2}$ and Miroslav Lalović ${ }^{2}$ \\ ${ }^{1}$ Faculty of Agriculture, University of Belgrade-Zemun, Belgrade, Serbia \\ ${ }^{2}$ Faculty of Agriculture, University of East Sarajevo, East Sarajevo, B\&H \\ *Corresponding author: e-mail: t.pand@yahoo.com
}

\begin{abstract}
The main objective of this study was to analyze the results of table egg production Lohmann Brown hybrid chickens before and after forced moulting, or study of the impact of forced molting on productivity and the duration of its lifetime hens. The surveys cover three periods, namely: - the first production of eggs in the first year (from 19 -71. Weeks of age hens); the second - moulting period (from $72-76$. Sunday); the third - after the forced molting period (from $77-106$. weeks of age hens). The experiment was conducted on a total of 44,400 commercial laying hens reared in a cage system, "enriched" cages, family farm "Rakic-Commerce" (Batkovic, Bijeljina, Republic of Serbian, BiH). From 19 to 48 weeks of age with a hen housed load intensity was $85,11 \%$, from 19 to 71 weeks of age to $82.49 \%$, while the second phase capacity uu after moulting after laying hen housed intensity of the load was $74.36 \%$. From 19 to 48 weeks of age mortality rate was $4.21 \%$, up $8.47 \% 71$ weeks, during moulting $1.35 \%$, from 77 to 106 weeks of age $3.24 \%$. Between the age of hens and intensity of capacity in the first 30 weeks egg production was determined by the mean positive correlation connection ( $\mathrm{rp}=$ 0.470) $(\mathrm{P}<0.01)$. In other phases of the production cycle of these indicators did not exist or were very weak negative correlation.
\end{abstract}

Key words: force molting, laying hen, hens age, intensity of load, mortality, production ages hens.

Received: 23.10.2016. Accepted: 10.122016. 


\section{Introduction}

The main reason for the implementation (application) forced (forced) molting hens the extension of their production period, usually 69 weeks at 105 to 110 weeks of hen. This rule increases the cost of the respective type of production, reduce the costs of procurement 18 weeks, while the market is continuously supplied eggs for consumption (Anderson, 2016a; Elson and Croxall, 2006; Senčić i Butko, 2006; Hassanien, 2011; Radovic , 2011; Pandurevic, 2011; Maslić- Strižak, 2012; Zemcov, 2015). Common methods of eating their food restrictions, water and light regime, ie the length of the light days and light intensity. At the poultry farm, "Rakic-Commerce" (Republic of Srpska, Bosnia and Herzegovina), which has a capacity of close to 200 thousand hens in a shift, often conducting the forced molting hens eggs for consumption. Therefore, the primary objective of this study to analyze the results of table egg production Lohmann Brown hybrid chickens after application of forced moulting and their comparison with the first year of exploitation hens. Special emphasis is given to mortality, the intensity of load, egg weight and food consumption in these periods. The monitored indicators will be compared before and after the completion of molting hens. In addition, in the end, found influence of age on the intensity of load hens eggs in different stages of the production cycle (before and after the forced molting hens) by calculating the correlation coefficients of phenotypic correlation.

\section{Materials and methods}

Studies productive characteristics of a commercial flock of laying hens Lohmann Brown hybrids were carried out at the poultry farm, which is part of the DOO "Rakic-Commerce", Batkovic, Bijeljina, Republic of Srpska, Bosnia and Herzegovina. The trial material for the monitoring and analysis of the productive traits has served a total of 44,400 hens. The period of egg production in the first phase lasted for 53 weeks (from 19 to 71 weeks), in the second 30 weeks (from 77 to 106 weeks of age hens) and between these two phases is carried out forced molting hens for five weeks or 35 days (table 1).

During breeding (egg production) commercial flock of laying hens has been kept in the so-called. "Enriched cages" and used the technology is growing, with slight modification, proposed by the respective line hybrid breeder hens (www.ltz.de). All technological stages are automatically regulated. The research can be divided into three parts, namely: - First production of eggs in the first year (from 19 -71. Weeks of age hens); second - moulting period (from 72 - 76 weeks); the third - after the moulting period (from 77 - 106 weeks of age hens). During this period (before, during and after molting), and during the growing commercial flock of laying hens to 106 weeks of age, special attention is paid to mortality, the intensity of load capacity, weight (class) eggs and feed consumption. 
Table 1 - Program of forced molting hens from 72 to 76 weeks of age

\begin{tabular}{ccccc}
\hline $\begin{array}{c}\text { Period moulting } \\
\text { (days) }\end{array}$ & $\begin{array}{c}\text { Length of light } \\
\text { day (hours) }\end{array}$ & $\begin{array}{c}\text { The intensity of of } \\
\text { lighting }\left(\mathrm{W} / \mathrm{m}^{2}\right)\end{array}$ & $\begin{array}{c}\text { Food per day } \\
\text { per hen }(\mathrm{g})\end{array}$ & $\begin{array}{c}\text { Water } \\
\text { and vitamins }\end{array}$ \\
\hline $1-7$ & 8 & 3 & 120 & ad lib. \\
$7-11$ & 8 & 3 & 120 & both \\
$12-13$ & 8 & 1 & no food & no water \\
$14-17$ & 8 & 1 & no food & both \\
18 & 8 & 1 & no food & water \\
19 & 8 & 1 & no food & water \\
20 & 8 & 2 & 120 & water \\
$21-22$ & 8 & 2 & 120 & both \\
$23-32$ & 8 & 2 & 120 & ad lib. \\
$33-35$ & 12 & 3 & 120 & ad lib. \\
\hline
\end{tabular}

The primary data processing was performed using the usual variational statistical methods (Hadživuković, 1991; Latinović, 1996).

\section{Results and Discussion}

Tables 2 and 3 shows the strength of hens and total mortality in the first 30 weeks before and after moulting, while Table 4 shows the average values of mortality hens at all stages of the production process analyzed concerned commercial flock of laying hybrids.

Table 2 - Movement in number of hens before, during and after forced moulting

\begin{tabular}{lcc}
\hline Indicators - The number and mortality of hens & Hen & \% \\
\hline Number of layers at the beginning of the first production cycle & 44.400 & 100,00 \\
Number of hens with 48 weeks of age - pre moulting (30 & 42.518 & - \\
weeks of production) & 1.882 & 4,21 \\
Mortality hens to 48 weeks of age the number of inhabited & 40.622 & - \\
Number of hens after the first production cycle (53 weeks) & 3.778 & 8,47 \\
Mortality from 19 to 71 weeks of age - 53 weeks of prod. & - & - \\
& 598 & 1,35 \\
Mortality during molting hens (5 weeks): & 598 & 1,47 \\
& 40.024 & - \\
The number of inhabited hens (hens 44.400) & - & - \\
& 1.440 & 3,24 \\
The number of pre molting hens (40,622 hens) & 1.440 & 3,54 \\
& 1.440 & 3,60 \\
Number of hens after moulting - the beginning of the second & 38.584 & - \\
cycle (30 weeks) & & \\
\hline
\end{tabular}


Data in table 2 show that at the beginning of the experiment was, or, according occupied 44.400 hens aged 19 weeks of gestation (number), pre moulting, ie. after 53 weeks of growing (exploitation) and egg production (first year - phase load) there were 40.622 hens after forced moulting in the house was 40,024 hens, when the flock is commercially extracted from the production process was the old 106 weeks and a total of was 38,584 hens. Slightly lower allcause mortality after housed hen $(8.07 \%)$ for 53 weeks of growing (20 - 72 weeks) found Pandurevic (2011) laying hens Lohman Brownn. Guesdon and Faure (2004) in the cultivation of a commercial flock of laying hens hybrids Isa Brownn to 70 weeks of age found higher mortality hens reared in conventional cages $(21 \%-17 \%)$, or "enriched" cages $(11 \%$ - 10\%). Depending on the method (system) hens, Elson and Croxall (2006), Tauson and Holm (2001) followed the productivity of 29 flocks of laying hens (several European countries), and up to 70 weeks of age found a different overall mortality hens. The "enriched" cages hens mortality was less than $8 \%$. In essence, these authors have obtained similar results with our results in terms of mortality hens reared pre moulting. Zemcov (2015) for 53 productive weeks laying hens reared in conventional cages found higher mortality $(8.46 \%)$ than in hens reared in "enriched" cages $(7.10 \%)$. Mortality hens first 30 weeks egg production and 30 weeks after molting (second stage) was approximately similar and hen housed at the beginning of the production of eggs and housed hen after moult was on average $0.12 \%$ and $0.11 \%$ per week (table 3).

Table 3-Average values and variability of mortality hens before and after moulting $(\%)$.

\begin{tabular}{|c|c|c|c|c|c|}
\hline Age/weeks of production & $\mathbf{n}$ & $\mathbf{x}$ & Sx & $\mathbf{S}$ & C.V. \\
\hline 19. - 48./1. - 30. (before moulting) & 30 & 0,14 & 0,01 & 0,06 & 42,86 \\
\hline 19. $-71 . / 1 .-53$. (first year) & 53 & 0,16 & 0,01 & 0,06 & 37,50 \\
\hline 72. - 76./ 1. - 5. (moulting) & 5 & 0,29 & 0,02 & 0,04 & 13,79 \\
\hline 77. - 106./1. - 30. (after moulting) & 30 & 0,11 & 0,004 & 0,02 & 18,18 \\
\hline 77. - 106./1. - 30. (after moulting) ${ }^{\mathrm{A}}$ & 30 & 0,12 & 0,005 & 0,02 & 20,83 \\
\hline 77. $-106 . / 1 .-30$. (after moulting) $^{\mathrm{B}}$ & 30 & 0,12 & 0,005 & 0,03 & 22,50 \\
\hline
\end{tabular}

A hen housed before moulting (40,622 hens).

B hen housed hen after moulting (40,024 hens).

From 19 to 48 weeks of age (30 production) per housed hen $(44,400$ hens) produced 178.74 eggs (intensity capacity $85,11 \%$ ), and from 19 to 71 weeks of age (a total of 53 weeks of production in the first cycle) 306,03 eggs (82.49\%), while in the second phase of capacity, after moulting, for 30 weeks per hen housed eggs produced 156.14 (74.36\%), then the hens culled from production when the age of 106 weeks. In addition, conditionally speaking after housed hen 
after moult (40,024 hens) produced 172.65 yolk or intensity of capacity amounted to $82.14 \%$ (tables 4 and 5).

Table 4 - The main indicators of of productivity eggs before and after moulting

\begin{tabular}{lcc}
\hline Indicators & Before moulting & After moulting \\
\hline Eggs per hen housed (19-48 weeks) & 178,74 & - \\
Eggs per hen housed (19 - 71 weeks & 306,03 & 156,14 \\
Eggs per hen housed (77 - 106 weeks A & - & 172,65 \\
Eggs per hen housed (77 - 106 weeks) B & - & - \\
The intensity of the load -\% (19-48 weeks) & 85,11 & - \\
The intensity of the load -\% (19 - 71 weeks) & - & 74,36 \\
& - & 82,14 \\
\hline
\end{tabular}

A inhabited 44,400 laying hens;

B inhabited after molting hens 40.024 .

The intensity of the pre load for the entire moulting period (53 weeks) amounted to $82.49 \%$ (table 5), which is in line with the technological standards recommended by the respective breeder hen hybrids.

Table 5 - Average values and variability of the intensity of load per hen housed 44,400 hens) before and after moulting (\%)

\begin{tabular}{lccccc}
\hline Age/weeks of production & $\mathbf{n}$ & $\mathbf{x}$ & $\mathbf{S x}$ & $\mathbf{S}$ & C.V. \\
\hline 19. - 48./1. - 30. (before moulting) & 30 & 85,11 & 3,32 & 18,16 & 21,34 \\
19. - 71./1. - 53. (first year) & 53 & 82,49 & 1.95 & 14,17 & 17,18 \\
77. - 106./1. - 30. (after moulting) & 30 & 74,36 & 1,84 & 10,08 & 13,55 \\
77. - 106./1. - 30. (after moulting) & 30 & 82,14 & 2,01 & 11,02 & 13,42 \\
\hline
\end{tabular}

* housed hen after moult (40,024 hens).

Statistically significant $(\mathrm{P}<0.01)$ were higher intensity load for $10.75 \%$, achieved hens in the first 30 weeks than after moulting, also for 30 weeks. Then, the intensity of the load after the forced molting was lower compared to the moulting period ( 53 weeks of production), $8.13 \%$, and the determined difference is confirmed at the level of $\mathrm{P}<0.01$. Similar studies were conducted Mitrovic et al. (1995), and our results were much worse than ours, because the intensity of capacity amounted to $78.57 \%$ (pre moulting) and $63.71 \%$ (after molting). MaslićStrižak (2009), hens Hy Line hybrid Mitar to 87 weeks of age (load intensity was $57,56 \%$ ), and the moulting period lasted 6 weeks, a second phase of egg after moulting 37 weeks. Up to 87 weeks of age after the hen housed $133 \mathrm{~g}$ of food consumed and produced 355 eggs, $4.85 \%$ were poor quality eggs with shells. In the second phase (37 weeks) per hen's eggs produced $170(65.64 \%)$, food 
consumption amounted to $135 \mathrm{~g}$, while $0.8 \%$ were fewer eggs with poor shell quality in relation to the first phase of egg production. For prolonged moulting (49 days) hens Isa Brown hybrid, which began at 80 weeks of age hens Ocak et al. (2004) in the first phase of the production cycle have been determined bearing capacity substantially lower intensity in all groups of layers (from $40.08 \%$ to $45.08 \%$ ). In relation to our research where the hens used in the second phase of 30 weeks, the authors mentioned second phase shortened to 21 a week and in addition, with respect to our results in all weight groups of hens determine the intensity of lower capacity than in a lake group of hens that have made a similar capacity $-72.17 \%$ and $-72.43 \%$ of our hens. In addition to forced moulting affects the number and percentage of eggs laid in the individual phases of the production cycle, molt, hens and age have a certain impact on the ground. Classes eggs, and egg weight are shown in table 6.

Table 6 - Classes eggs per weight groups during the first 30 weeks of production (19 - 48 weeks old hens) and after molting (77 - 106 weeks of age)

\begin{tabular}{|c|c|c|c|c|c|c|}
\hline $\begin{array}{l}\text { Period of } \\
\text { production }\end{array}$ & $\begin{array}{c}\text { Num. } \\
\%\end{array}$ & $\begin{array}{c}\text { "S" } \\
<53 \text { g } \\
\end{array}$ & $\begin{array}{c}\text { "M" } \\
53-63 \text { g } \\
\end{array}$ & $\begin{array}{c}\text { "L" } \\
63-73 \text { g }\end{array}$ & $\begin{array}{l}X L " \\
>73 \mathrm{~g} \\
\end{array}$ & $\begin{array}{c}\text { Total } \\
\text { eggs }\end{array}$ \\
\hline Before & Eggs & 568.720 & 4.634 .663 & 2.551 .983 & 182.092 & 7.937 .458 \\
\hline moulting & $\%$ & 7,17 & 58,39 & 32,15 & 2,29 & 100,00 \\
\hline After & Eggs & 440.308 & 3.709 .883 & 2.593 .208 & 190.574 & 6.933 .973 \\
\hline moulting & $\%$ & 6,35 & 53,50 & 37,40 & 2,77 & 100,00 \\
\hline
\end{tabular}

The data in table 6 shows that the observed by classes of eggs, before and after moulting the largest relative share of eggs was in class "M" $(58.39 \%$ and $53.50 \%)$ and lowest in class "XL" (2, 29\% and 2.77\%). Pandurevic (2011) is the largest relative share of eggs found in Class "L" (49.09\%), followed by "M" $(38.57 \%)$ and "XL" (7.68\%) and the least in the "S" class $(4.66 \%)$, but for the 53week production cycle. The author has found that with age hens increases egg weight of the dissemination by the end of the production cycle. Egg weight with age hens increased before and after molting. No matter what you are after molting hens, compared with the beginning of production of eggs (the first 30 weeks payload eggs), carried the weight of the eggs, between the age of hens and eggs in the mass production of both periods revealed the absolute positive correlation connection and phenotypic correlation coefficients $(\mathrm{rp}=\mathrm{rp}=0.925$ and 0.969$)$ were statistically confirmed at the level of $\mathrm{P}<0.001$.Very interesting studies (two recent tests) were conducted in North Carolina, and the reason was an epidemic of bird flu, and therefore a lack of potential hens eggs for consumption. Anderson (2016bc), among other things, tried to answer the question of why the use of forced molting of commercial flock of laying hens "popular" in the US than in Europe (Germany) and under which conditions molting hens can be economically justified. These authors examined or tested 
more productive genotypes (strains) that hens lay eggs white and brown shell and grown in the United States and Germany. Tests carried out indicate that the induction of forced molting economically justified if the hens held to 109 weeks of age, and if during the moulting period not to lose more than $20 \%$ of body weight. Program restrictions on food, that is. period of fasting during molting hens shown in table 1, a daily feed consumption per hen and egg produced before and after the forced molting hens, and for the first phase growing in table 7.

Table 7 - Consumption of food during the growing commercial flocks produced by hens and egg

\begin{tabular}{lcc}
\hline Indicators & Before moulting & After moulting \\
\hline Daily food per hen $(19-48$ weeks $)$ & $126,72 \mathrm{~g}(26,61 \mathrm{~kg})$ & - \\
Daily food per hen $(19-71$ weeks) & $132,24 \mathrm{~g}(49,06 \mathrm{~kg})$ & - \\
Daily food per hen $(77-106$ weeks $)$ & - & $122,00 \mathrm{~g}(25,62 \mathrm{~kg}))$ \\
Food per egg g $(19-48$ weeks $)$ & 148,87 & - \\
Food per egg g $(19-71$ weeks) & 160,31 & - \\
Food per egg g $(77-106$ weeks $)$ & - & $164,08(148,39)$ \\
\hline
\end{tabular}

Daily consumption of feed per hen housed was the largest (132.24 g) in a flock which has grown the entire production cycle, and the smallest $(122.00$ g) when grown after molting hens to 106 weeks of age (table 7). In the second cycle of egg production, feed consumption per egg produced, compared to the first year of rearing laying hens, or pre moulting, was significantly higher and amounted to $164.08 \mathrm{~g}$ and $148.29 \mathrm{~g}$, and was above the upper limit of technological norms of the respective hybrid. In layers Lohman Brownn from 20 to 72 weeks egg production Pandurević (2011) found that the daily consumption per hen housed was $126.97 \mathrm{~g}$ per egg produced $151.47 \mathrm{~g}$, as compared to our results to some custom favorable. Significantly lower daily feed consumption per hen they found Elson and Croxall (2006) both in standard cages $(110.8 \mathrm{~g})$, and "enriched" cages $(104.7 \mathrm{~g})$ in breeding hens to 70 weeks of age. It should be noted that the values of correlation coefficients between age and intensity of hens capacity to some extent show how justified the duration of the useful life of laying hens (table 8).

Between the age of hens and intensity in the first 30 weeks egg production was determined by medium positive correlation connection $(\mathrm{rp}=0.470)$ and the coefficient of phenotypic correlation was statistically significant ( $\mathrm{P}$ $<0.01)$. However, in other phases of the production cycle of these indicators there was no phenotypic correlation connection (table 8). 
Table 8 - The coefficients of phenotypic correlation (rp) between the age of hens and intensity of load per hen housed, $\%$ (44,400 hens)

\begin{tabular}{cccc}
\hline $\begin{array}{c}\text { Age/ } \\
\text { production }\end{array}$ & $\mathbf{r}_{\mathbf{x y}}$ & $\mathbf{t}_{\text {exp }}$ & $\begin{array}{c}\text { The strength of } \\
\text { correlation }\end{array}$ \\
\hline $48 / 30$ & $0,421^{* *}$ & 2,928 & Medium \\
$49 / 31$ & $0,415^{*}$ & 2,456 & Medium \\
$50 / 32$ & $0,407^{*}$ & 2,440 & Medium \\
$51 / 33$ & $0,406^{*}$ & 2,474 & Medium \\
$52 / 34$ & $0,377^{*}$ & 2,303 & Weak \\
$53 / 35$ & $0,357^{*}$ & 2,195 & Weak \\
$54 / 36$ & $0,329^{*}$ & 2,031 & Weak \\
$55 / 37$ & $0,303^{\mathrm{NS}}$ & 1,881 & Weak \\
$56 / 38$ & $0,276^{\mathrm{NS}}$ & 1,723 & Weak \\
$57 / 39-63 / 45$ & $0,249^{\mathrm{NS}}-0,115^{\mathrm{NS}}$ & $1,564-0,759$ & Very weak \\
$64 / 46-70 / 52$ & $0,095^{\mathrm{NS}}--^{-0,044^{\mathrm{NS}}}$ & $0,633-0,311$ & No \\
$71 / 53$ & $-0,074^{\mathrm{NS}}$ & 0,530 & No \\
$106 / 88 / 30$ & $-0,201^{\mathrm{NS}}$ & 1,085 & Very weak \\
$106 / 88 / 30^{\mathrm{A}}$ & $-0,209^{\mathrm{NS}}$ & 1,131 & Very weak \\
\hline
\end{tabular}

NS $\mathrm{P}>0.05 ; * \mathrm{P}<0.05 ; * * \mathrm{P}<0.01 ; * * * \mathrm{P}<0.001$

A housed hen after moult (40,024 hens).

These coefficients indicate the conclusion that analyzed flock should not be used more than 53 weeks ( 71 weeks of age hens), and after moulting no longer than 30 weeks (106 weeks of age hens). Similarly, Pandurevic (2011) and Zemcov (2015) in a commercial flock of laying hens hybrids Lohman Brown grown only in the first cycle without molting.

\section{Conclusion}

The research conducted on 44,400 commercial laying hens reared in a cage system (the so-called. "Enriched" cages) family farm "Rakic-Commerce" (Batkovic, Bijeljina, Republic of Srpska, BiH) show that the use of forced molting yielded positive results in terms of prolonging the period for hens to 106 weeks of age because the hens produce more eggs and better quality (weight) of eggs, hens, and the mortality was within acceptable limits at all stages of the production cycle (before, during and after molting). Although it should be noted that the coefficients of phenotypic correlation between the age of hens and monitored indicators point to the conclusion that the analyzed flock should not be used more than 53 weeks ( 71 weeks of age hens), and after moulting no longer than 26 to 30 weeks (106 weeks of age hens ). As for the significance difference was found to be statistically significant $(\mathrm{P}<0.01)$ higher intensity of capacity, for $10.75 \%$, achieved hens in the first 30 weeks than after moulting, also for 30 weeks. However, if the intensity of the converted payload instead of 44,400 to 
44,024 immigrants hens laying hens, how many were following moulting after laying hen housed the number of eggs produced solid (172.65 eggs), and the intensity of load amounted to $82.14 \%$, and the weight of the eggs is was higher.

\section{References}

Anderson K.E. (2016a): Induced Molting as a Managnent Tool. NC State University. Anderson K.E. (2016b): Induced Molting of Commercial Layers. NC Stata University. Anderson K.E. (2016c) - (Flock dkflock@t-online.de): Molting of laying hens: test results from north Carolina and imolications for US and German egg producers.

Elson H.A., Croxall R. (2006): European study on the comparative welfare of lazing hens in cage and non-cage szstems. Arch. Geflügelk., 70 (5): 194-198.

Guesdon V., Faure J. M. (2004): Laying performance and egg quality in hens kept in standard of furnished cages. Anim. Res., 53, 45-57.

Hassanien H.H.M. (2011): Effect of force molting bprograms on egg production and quality of laying hens. Asian Journal of Poultry Science, 5: 13-20.

http://www.ltz.de

Hadživuković S. (1991): Statistički metodi s primenom u poljoprivrednim i biološkim istraživanjima. Novi Sad.

Latinović D. (1996): Populaciona genetika i oplemenjivanje domaćih životinja (praktikum). Univerzitet u Beogradu, Poljoprivredni fakultet, Beograd-Zemun..

Maslić Strižak Danka (2012): The results of molting bearing hens, Macedonian Journal of Animal Science, Vol. 2, No. 2, pp. 155-158.

Ocak N, Sarica M., Erener G., Garipoglu A. V. (2004): The effect bof body weight prior to molting in brown laying hens on egg yield and quality during second production cycle. International Journal of Poultry Science 3 (12): 768-772.

Pandurević Tatjana (2011): Uticaj starosti na proizvodnost, kvalitet i hemijski sastav jaja lakog linijskog hibrida kokoši. Doktorska disertacija. Poljoprivredni fakultet, Univerzitet u Istočnom Sarajevu, Istočno Sarajevo.

Radović Sanja (2011): Utjecaj različitih načina smještaja i držanja na zdravlje, dobrobit i proizvodnost kokoši nesilica. Doktorska disertacija, Sveučilište u Zagrebu, Veterinarski fakultet, Zagreb.

Senčić Đ., Butko Danijela (2006): Proizvodnost nosilja i kvalitet kokošijih jaja iz slobodnog držanja. Agriculture, Vol. 12, 2, 48-51.

Tauson R., Holm K.E. (2001): First furnished small grup cages for laying hens in evaluation program on commercial farms in Sweden. Proc. 6th Europen Symposium on Poultry Welfare. Zollikofen.

Zemcov Dragana (2015): Uticaj sistema držanja nosilja na produktivnost komercijalnog jata kokoši hibrida Lohmann Brown. Master rad. Poljoprivredni fakultet, Univerzitet u Beogradu, Beograd. 


\title{
UTICAJ PRINUDNOG MITARENJA NA PRODUKTIVNOST I TRAJANJE PROIZVODNOG CIKLUSA KOMERCIJALNIH KOKOŠI NOSILJA DRŽANIH U KAVEZNOM SISTEMU
}

\author{
Sreten Mitrović ${ }^{1}$, Tatjana Pandurevic ${ }^{2^{*}}$, Maja Radoičić Dimitrijević ${ }^{1}$, \\ Milena Milojević ${ }^{1}$,Julijana Trifković ${ }^{2}$, Miroslav Lalović ${ }^{2}$ \\ ${ }^{I}$ Poljoprivredni fakultet, Univerzitet u Beogradu-Zemun, Srbija \\ ${ }^{2}$ Poljoprivredni fakultet, Univerzitet u Istočnom Sarajevu, BiH \\ e-mail:t.pand@yahoo.com
}

\begin{abstract}
Rezime
Osnovni cilj ovog rada bio je analiza rezultata proizvodnje konzumnih jaja Lohmann Brown hibrida kokoši pre i posle prinudnog mitarenja, odnosno ispitivanje uticaja prinudnog mitarenja na produktivnost i trajanuje proizvodnog veka nosilja. Istraživanjima su obuhvaćena tri perioda, i to: prvi - produkcija jaja u prvoj godini (od 19. -71. nedelje starosti nosilja); drugi - period mitarenja (od 72. -76. nedelje); treći - period posle prinudnog mitarenja (od 77. -106. nedelje starosti nosilja). Eksperiment je sproveden na ukupno 44.400 komercijalnih nosilja gajenih u kaveznom sistemu ("obogaćeni" kavezi) na porodičnom gazdinstvu "Rakić-Komerc" (Batković, Bijeljina, Republika Srpska, BiH). Od 19. do 48. nedelje starosti (30. proizvodnje) po useljenoj nosilji proizvedeno je 178,74 jaja (intenzitet nosivosti $85,11 \%$ ), a od 19. do 71 . nedelje starosti (ukupno 53 nedelje proizvodnje u prvom ciklusu) 306,03 jaja (82,49\%), dok je u u drugoj fazi nosivosti, posle mitarenja, za 30 nedelja (druga faza - ciklus proizvodnje) po useljenoj nosilji proizvedeno 156,14 jaja $(74,36 \%)$ i tada su nosilje izlučene iz proizvodnje i bile su stare 106 nedelje. Od 19. do 48. nedelje starosti mortalitet je $4,21 \%$, do 71 . nedelje $8,47 \%$ ), za vreme mitarenja $1,35 \%$, a u drugom ciklusu $3,24 \%$. Pored toga, između starosti nosilja i intenziteta nosivosti u prvih 30 nedelja produkcije jaja utvrđena je srednja pozitivna korelaciona povezanost $\left(\mathrm{r}_{\mathrm{p}}=\right.$ $0,470)$ i koeficijent fenotipske korelacije je bio statistički signifikantan $(\mathrm{P}<0,01)$.
\end{abstract}

Ključne reči: prinudno mitarenje, nosilje, uzrast nosilja, intenzitet nosivosti, smrtnost, proizvodni uzrast nosilja. 